\title{
VSY1-1 霊長類動物を用いた異分野連携による子宮移植手術技術の開発
}

木須伊織 ${ }^{1,2}$, 加藤容二郎 ${ }^{3}$, 山田洋平 ${ }^{4}$, 松原健太郎 ${ }^{5}$, 尾原秀明 ${ }^{5}$, 佐伯陽子 ${ }^{6}$, 原尚子 ${ }^{7}$, 三原誠

${ }^{1}$ 国家公務員共済組合連合会 立川病院 産婦人科, ${ }^{2}$ 慶應義塾大学 医学部 産 婦人科学教室, ${ }^{3}$ 国際医療福祉大学 三田病院 移植外科, ${ }^{4}$ 慶應義塾大学 医学 部 小児外科学教室, 慶應義塾大学 医学部 外科学教室, ${ }^{6}$ 済生会神奈川県病 院 麻酔科, ${ }^{7}$ 東京大学 医学部附属病院 形成外科 - 美容外科, ${ }^{8}$ 埼玉県済生会 川口総合病院 リンパ外科・再建外科

【目的】近年，子宮性不妊女性に対する治療しして子宮移植が考えられている。子宮 移植は産婦人科及び移植医療の両者の領域に跨り, 科を越えた異分野連携により達成 される技術である。今回我々は，異分野領域の連携を図りながら，カニクイザルを用い て子宮移植手術技術の開発を行つたので報告する.【方法】実験施設の倫理委員会 承認の下，カニクイザルを用いて，子宮移植手術を行った。1. 自家移植：血管柄付き 子宮を体外に摘出し, 冷却しながら臓器灌流させ，摘出子宮を術野に同所性に戻した。 腟吻合後，顕微鏡下で血管吻合を行い閉腹した。2. 同種移植 : 血液型一致 , MHC 不 一致のカニクイザルをレシピエント / ドナーに分け, ドナーを開胸開腹し, 外腸骨動脈 に灌流用カテーテルを留置した。ヘパリン静注し, 腹腔動脈上で大動脈を遮断し, 胸腔 内で下大静脈を切断した。灌流用カテーテルより灌流液を注入し, 腹腔内全臓器を灌 流後, 子宮グラフトを体外に摘出し, 自己子宮摘出後のレシピエントへ子宮グラフトを移 植した。腟吻合後に血管吻合し，閉腹した。いずれも術後，月経の確認，経腹超音波 断層法，子宮頸部生検を定期的に施行した。【成績】自家移植個体において，移植 後に自然妊娠し，満期に帝王切開により生児を得た。同種移植個体では，一部の個体 で拒絶反応を認めたが, 術後月経の回復がみられた。【結論】異分野連携により子宮 移植の手術技術開発が可能であることが示唆された。

\section{VSY1-2腹腔鏡亡胸腔鏡を併用し肝、横隔膜および肺合併切除を行った卵巣癌 腹膜播種の一例}

中平伸 ${ }^{1}$, 伊禮俊充 ${ }^{2}$, 井上雅史 ${ }^{2}$, 山崎友美 ${ }^{3}$, 水之江知哉 ${ }^{3}$, 原田洋明 ${ }^{4}$, 山下芳典 ${ }^{4}$, 岸本朋也 ${ }^{1}$, 山本為義 ${ }^{1}$, 大里浩樹 ${ }^{1}$, 畑中信良

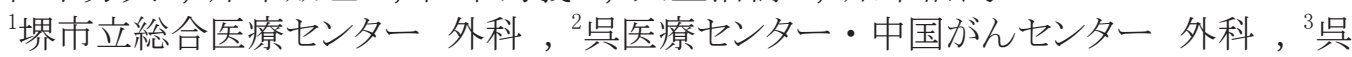
医療センター・中国がんセンター 産婦人科， 吳医療センター・中国がんセンター 呼吸器外科

【はじめに】腹腔鏡下肝切除において、肝腫瘍の横隔浸潤部は小範囲であれば自動 縫合器にて処理した後に通常の手順で手術可能である。一方で、広範囲の横隔膜合 併切除を要する症例では手術手技の工夫が必要である。卵巣癌の横隔膜下の播種病 巣に対して胸腔鏡と腹腔鏡を併用した横隔膜肝肺合併切除を行った症例を経験したの で報告する。【症例】症例は 58 歳, 女性。卵巣癌に対して子宮全摘、両側付属器切除、 大網切除、後腹膜リンパ節郭清を施行された。術後 7 年目に横隔膜下に径 $6 \mathrm{~cm}$ の腹 膜播種再発をきたし、肝、横隔膜、肺へ広範囲の浸潤が疑われた。肝十二指腸間膜 リンパ節転移も認め、鏡視下に肝部分切除とリンパ節摘出を行った。横隔膜切除範囲 を可及的に小範囲にして人工物による横隔膜再建を回避し（肝切離面に人工物が接す る）、気腹圧が胸腔にかかる時間を短時間にするために肝切離を先行した。その際に 横隔膜浸潤部位周囲のテーピングよる挙上と経胸腔ポー卜留置が有効であった。肺浸 潤も疑われたため、横隔膜切離は胸腔鏡補助下に行った。横隔膜欠損部は鏡視下に 縫合閉鎖可能であった。手術時間 8 時間 40 分、出血量 50cc、術後 5 日目に退院した。 【結語】本症例において腹腔鏡と胸腔鏡の併用手術は低侵襲で有効な治療手技と考え られた。 
VSY1-3 肝下部下大静脈腫瘍栓を伴う腎癌に対するコラボレーション手術手技

春山泰治 ${ }^{1}$, 近藤靖司 ${ }^{2}$, 片山康 ${ }^{3}$, 鹿股宏之 ${ }^{1}$, 西原悠樹 ${ }^{1}$, 大野俊一 ${ }^{2}$,

手島太郎 ${ }^{2}$, 松永裕樹 ${ }^{3}$, 三島秀樹 ${ }^{3}$, 梅北信孝

都立墨東病院 外科, ${ }^{2}$ 都立墨東病院 泌尿器科, ${ }^{3}$ 都立墨東病院 心臓血管外 科

【目的】腎癌の腫瘍栓が肝下部下大静脈まで充満する症例では複数科による安全な手 術計画、手技が必要となる。当院における、腎癌肝下部下大静脈腫瘍栓症例に対す る泌尿器科、外科、心臓血管外科によるコラボレーション手術を供覧し手技を検討する。 【方法】対象は、最近 1 年間で肝下部下大静脈に腎癌腫瘍栓が充満した 2 症例。術 前に泌尿器科、外科、心臓血管外科、麻酔科で術前カンファランスを行い、下大静脈 合併切除再建の手順を検討した。【成績】症例 1:73 歳、女性。左腎癌から左腎静 脈を介し、肝下部下大静脈に充満する腫瘍栓を伴っていた。肝静脈根部は辛うじて開 存していた。症例 $2: 70$ 歳、男性。右腎癌から肝静脈根部付近まで腫瘍栓が進展し ていた。泌尿器科により腎摘手技を先行した後、外科により右肝脱転、短肝静脈の完 全処理、肝静脈根部のテーピングを行った。肝上で下大静脈をテーピングした。心臓 血管外科により腎下大動脈、下大静脈（腎下 $\rightarrow$ 腎静脈 $\rightarrow$ 腎上）を順次クランプし血圧 を保ちながら下大静脈を切開し、腎静脈腫瘍栓を摘出後、縫合閉鎖した。肝下部下大 静脈を完全に露出しておくことで安全に腫瘍栓を摘出し再建することができた。術後は 順調に経過し症例 1 は 25 病日、症例 2 は 11 病日に退院となった。【結論】肝下部下 大静脈まで腫瘍栓が充満する腎癌症例では、各科の専門技術をコラボレーションするこ とで安全に切除することができる。

\section{VSY1-4 乳癌手術と同時に行う腹部遊離皮弁を用いた乳房再建術}

藤田和敏 ${ }^{1}$, 曾束洋平 ${ }^{1}$, 藤原敏弘 ${ }^{1}$, 河合建一郎 ${ }^{1}$, 西本聡 ${ }^{1}$, 垣淵正男 ${ }^{1}$, 三好康雄 ${ }^{2}$

${ }^{1}$ 兵庫医科大学病院 形成外科, ${ }^{2}$ 兵庫医科大学病院 乳腺 - 内分泌外科 乳癌患者数は年々増加傾向にあり、それに伴い当院でも形成外科と乳腺外科との協力 手術症例（乳房再建手術症例）が増加傾向にある。再建方法は、シリコンインプラント を用いた人工物再建と、自家組織再建の二つに大きく分けられる。自家組織による乳 房再建を行う場合、当院では腹部遊離皮弁による再建を選択する場合が多い。今回わ れわれは、腹部遊離皮弁による一次一期乳房再建手術症例を重ねるにあたつて、いく つかの工夫、改良を行ってきたので、ビデオを供覧しながら報告する。皮弁デザインは、 術前に撮影した CT 画像を、プロジェクタを用いて患者の腹部に投影ながら深下腹壁 動脈および穿通枝をトレースし、皮弁への血行および穿通枝の確認している。これによ り皮弁の栄養血管に関する全体のイメージがつきやすく、手術経験の浅い医師に対して 教育的な効果も高いと考えられる。挙上した皮弁の血流評価は、当初は皮弁からの出 血の色調で評価していたが、現在は、血管吻合後インドシアニングリーン蛍光造影法 （ICG）を用い、客観的な Zone2 温存範囲の指標としている。乳房マウンド作成では、 術前に患者正面より多方向から乳房の撮影を行った画像を基に、家庭用パーソナル $3 \mathrm{D}$ プリンタ - で乳房テンプレートを作成し、乳房マウンド作成の一助としている。 


\section{VSY1-5 食道癌サルベージ手術における他科とのコラボレーション手術}

西田卓弘 ${ }^{1}$, 川畑隆之 ${ }^{2}$, 守永圭吾 ${ }^{3}$, 落合昂一郎 ${ }^{1}$, 濱田朗子 ${ }^{1}$, 中尾大伸 ${ }^{1}$, 松久保眞 ${ }^{1}$, 田代耕盛 ${ }^{1}$, 土屋和代 ${ }^{1}$, 河野文彰 ${ }^{1}$, 池田拓人 ${ }^{1}$, 東野哲也 ${ }^{2}$, 七島篤志 ${ }^{1}$

1宮崎大学医学部附属病院 消化管 - 内分泌 - 小览外科， ${ }^{2}$ 宮崎大学医学部附属 病院耳鼻いんこう・頭䅡部外科, ${ }^{3}$ 宮崎大学医学部附属病院 形成外科

食道癌の根治手術は、臓器の解剖学的特殊性や特有な合併症が関連し、従来より消 化器外科、胸部外科、麻酔科はもちろん、耳鼻咽喉・頭䅡部外科、形成外科なじ、 多くの科が手術に携わり、その周術期管理には歯科による口腔内ケア、発生や嬹下、 ADL 改善に関わるリハビリテーションや栄養管理など、多職種が連携して行う治療であ る。近年、根治的化学放射線療法 (definitive chemoradiotherapy; dCRT) 後の遺残 ・ 再発に対するサルベージ手術への期待が高まっており、年々症例数が増加傾向にある。 サルベージ手術の難度の高さや複雑化に加え、手術関連死亡を含めた重篤な合併症 の発生率の高さを背景とし、これまで以上の他科、他職種との協力・連携が必要とされ ている。今回我々は、頚部食道癌 [ CeUt $(16-23 \mathrm{~cm})$, type 3+0-Ilb, cT4b(気管、甲状腺) N1M0, cStage IVa ], dCRT 後遺残再発に対して、消化器外科、頭䫁部外科、形成外 科が共同で行った下咽頭喉頭食道全摘術、細径胃管による咽頭胃管再建術、両頸部 郭清 (II 〜 IV)、縦隔気管孔造設 (グリロー手術)、右大胸筋弁による縦隔再建術のビ デオを供覧しながら、当科における他科とのコラボレーション手術の現状を報告する。

\section{VSY1-6 当院における胃腫瘍に対する内視鏡治療と腹腔鏡治療のコラボレーショ ンについて}

榎本武治，民上真也，真船太一，福岡麻子，佐治攻，松下恒久，大坪毅人 聖マリアンナ医科大学 消化器・—般外科

近年、胃癌に対する腹腔鏡下手術は腹腔鏡に特化した術式の開発ならびにその定型 化と標準化が進み、その治療成績も明らかになりつつある。胃粘膜下腫瘍に対しても積 極的に腹腔鏡手術が行われている。部分切除が難しい症例に対しては腹腔鏡内視鏡 合同手術（Laparoscopic and endoscopic cooperative surgery: LECS）の報告が散見さ れ、腹腔鏡と内視鏡を併用することで過不足のない腫瘍切除が可能とされている。胃 腫瘍に対して腹腔鏡手術・内視鏡治療は当院でも行われてきたが、実際に手術室に おいてこの二つの治療を同時に運用するにあたり、外科、内科、麻酔科、手術部看護 師と話合いを行い、マニュアル化を行い、適宜更新してきた。当科における手術適応、 器械、体位、ポート配置、手技、現在までに 12 例に施行した結果について報告する。 
VSY1-7 心臓血管外科とコラボレーションして行う下大静脈合併切除再建を併施し た肝切除術

松尾憲一 ${ }^{1}$, 菊地祐太郎 ${ }^{1}$, 川口大輔 ${ }^{1}$, 村上崇 ${ }^{1}$, 廣島幸彦 ${ }^{1}$, 佐塚哲太郎 ${ }^{1}$, 平野敦史 ${ }^{1}$, 森幹人 ${ }^{1}$, 小杉千弘 ${ }^{1}$, 首藤潔彦 ${ }^{1}$, 宮澤幸正 ${ }^{1}$, 幸田圭史 ${ }^{1}$, 服部隆司 ${ }^{2}$, 田中邦哉 ${ }^{1}$

${ }^{1}$ 帝京大学ちば総合医療センター 外科, ${ }^{2}$ 千葉メディカルセンター 心臓血管外科

【背景】下大静脈浸潤転移性肝腫瘍に対して、根治性追求のため下大静脈合併切除 再建を伴う肝切除が必要となる場合がある。【目的】肝部 IVC 合併切除を伴う肝切除 時の体外循環回路併施の有用性を検討寸る。【手技】1）開腹前に体外循環回路構築 に備えて左大腿静脈、左鎖骨下静脈を露出。2）開腹後、肝を左右から完全脱転し、 肝上部 IVC、肝下部 IVCをそれぞれテーピング。3) Hanging maneuver を応用して肝 離断を施行。4）IVC のクランプテストを行い循環動態維持困難な場合は、大腿静脈か ら脱血し腋窩静脈一送血する体外循環回路を心臓血管外科医と共に確立。5）肝部 IVC とともに一括して腫瘍を摘出し、リング付ゴアテックスグラフトを用いて IVC を再建。 【成績】 6 例に肝部 IVC 合併切除再建（グラフト置換 5 例、心膜パッチ 1 例）を行い、 亏ち 2 例で体外循環回路を併用した。手術時間（中央值）は557 分、出血量は $1274 \mathrm{ml}$ 、肝部 IVC 再建時間は 38 分（体外循環併施 39 分 vs. 体外循環無 38 分）、 Clavien-Dindo IIIa 以上の合併症発生率は $33 \%$ と安全に施行可能であった。体外循環 併施の有無で短期成績、長期成績に差を認めなかったが、全例の生存期間中央値は 19.6 力月で術後観察期間短期生存 1 例（5.6 力月）を除いて、全例 1 年以上生存した。 【結語】肝部 IVC 合併切除再建を伴う肝切除では、体外循環に精通している心臓血管 外科とコラボレーションし体外循環を確立して同手技を行うことは安全性の面から重要で ある。

\section{VSY1-8 他科との協力や様々な準備による巨大後腹膜腫瘍に対する下大静脈合 併肝切除}

有泉俊一, 山下信吾, 高橋豊, 大森亜紀子, 渋谷豪, 土井愛美, 米田五大, 尾形哲, 植村修一郎, 谷澤武久, 小寺由人, 樋口亮太 , 片桐聡, 江川裕人, 山本雅一

東京女子医科大学消化器外科

目的 : 肝癌や後腹膜腫瘍は下大静脈（IVC）に浸潤圧排することがある。肝上部や肝 部 IVC に病変が及ぶ場合には肝切除に IVC 合併切除が必要となるが大量出血や血圧 低下など手術リスクが高い。方法：当院での他科との協力や準備・対策としては、1. IVCのどの部位に浸潤してるのか? 2. 副側血行路は？3. 右肝または左肝切除? 4. IVC の血行遮断方法は？ 5. ME と静脈 - 静脈バイパスの方法は? 6. 人工血管は? 循環器外科の協力は? 7. 抗血栓治療は? 8. 麻酔科は? 9. 内分泌科による術前 血圧管理は? 10。腎臟科による腎機能評価は? 11。ハイリスク検討会は?などである。 巨大右副腎褐色細胞腫の症例の対策とビデオを供覧する。成績 : 60 歳代の男性。主 訴は下腿浮腫である。巨大 $(20 \mathrm{~cm})$ 右副腎褐色細胞腫と診断した。腫瘍により肝下部 から肝部 IVC が完全閉塞していた。静脈造影で上行腰静脈を介し副側血行路を認めた。 腫瘍が右肝を強く圧排しており右肝切除を行った。肝静脈流入部より足側で IVC 離断 した。静脈 - 静脈バイパスと人工血管は準備したが使用しなかった。麻酔科による血圧 コントロールと低 CVP 麻酔が不可欠であった。内分泌科による術前からの血圧コントロー ルも必要であった。右腎は摘出した。左腎静脈は切離し非再建とした。本症例は合併 症なく退院した。結語 : 他科との協力や様々な準備・対策により巨大な後腹膜腫瘍で もより安全な IVC 合併切除を伴う肝切除が可能である。 


\section{VSY1-9}

山崎麻美

社会医療法人愛仁会高槻病院小览脳神経外科

小児脳神経外科では中枢性先天性疾患・小览脳腫瘍・小览脳血管障害・てんかん や痤縮などの機能外科・小览頭部外傷と、小览中枢神経疾患の様々な分野を外科的 に治療する診療科である。そのために、他科とのコラボレーション手術も多岐にわたる。 最近では先天性中枢疾患の多くは胎内で診断され、我々の病院では多職種からなるプ レネータルサポートチームにおいて胎児期から治療方針を決めていく。先天性疾患の 多くは、多発奇形を伴うことが多く、食道閉鎖、十二指腸閉鎖、鎖肛など小巟外科疾 患や、あるいは先天性心疾患の女る場合は、その優先順位を決め、綿密な打ち合わ せで治療にあたる。その中で、脳室腹腔手術後の囊胞形成では小览外科とのコラボレー ション手術、脳瘤術後の皮膚移植や骨形成術での形成外科とのコラボレーション手術、 また感染率の高いとされている春髄髄膜瘤手術においても産科との共同で、帝王切開 から手術に至る時間をできるだけ短くすることによって、髄膜瘤修復術と脳室腹腔シャン 卜術の同時手術で著しく感染率を下げることができている例などを供覧したい。

\section{VSY2-1＼cjkstart経腔的胆囊摘出を伴う腹腔鏡下胆囊摘出術の経験}

多賀谷信美 ${ }^{1}$, 嶋田まゆか ${ }^{1}$, 箱崎悠平 ${ }^{1}$, 山口夏希 ${ }^{1}$, 大矢真理子 ${ }^{1}$, 松永慶廉 ${ }^{1}$, 立岡哲平 ${ }^{1}$, 久保田和 ${ }^{1}$, 齋藤一幸 ${ }^{1}$, 山形幸徳 ${ }^{1}$, 奥山隆 ${ }^{1}$, 菅又嘉剛 ${ }^{1}$, 大矢雅敏 ${ }^{1}$, 榎本英夫 ${ }^{2}$, 高倉聡 ${ }^{2}$

獨協医科大学 越谷病院 外科, ${ }^{2}$ 獨協医科大学 越谷病院 産婦人科

「はじめに」既存の内視鏡下手術器具にて実行可能で、従来の手術に比べより低侵襲 性を提供でき、最小限の腹壁破壊を可能にする Natural orifice を利用した標本摘出法 として経腔ルートを利用した腹腔鏡下胆囊摘出術を婦人科医師とともに施行し、良好な 成績を示したので報告する。「対象および方法」 2012 年 5 月より現在までに経験した 症例は 4 例で、平均年齢は 60 歳 (39-81)、2 例に腹部手術既往があった。ポートは 臍部に $5 \mathrm{~mm}$ 、心窩部および右季肋下に $3 \mathrm{~mm}$ を刺入した。3 例は通常の腹腔鏡下ある いは細径内視鏡下に胆囊摘出を行い、胆囊を回収バッグに収納後、後膣円蓋より $12 \mathrm{~mm}$ ポートを挿入し、そこより体外に摘出した。残る 1 例は経腔的に $12 \mathrm{~mm}$ ポートを留 置後、そこより挿入した長さ $60 \mathrm{~cm}$ で外経 $5 \mathrm{~mm}$ の $30^{\circ}$ 斜視型硬性内視鏡観察下に腹 部に挿入した臍部および心窩部のポートより胆嚢摘出を行い、経腔的に胆囊を体外に 摘出した。腔孔は体外より縫合閉鎖した。「結果」4 例全例が完遂され、手術時間は 平均 64.5 分 (46-85)、1 例のみ術後に鎮痛剂を 1 回使用した。下腹部や膣の痛みは 認められず、術中偶発症や術後合併症は認められず、術後在院日数は平均 3 日 (2-4) であった「「結語」本法は経腔的に胆囊を取り出すことで、創痛の軽減および整容面 の向上が得られ、女性に対する腹腔鏡下胆囊摘出術の有効な選択肢の一つに成りうる と思われた。 


\section{VSY2-2 当科における他科とのコラボレーション手術の検討}

高橋玄 ${ }^{1}$, 塚本亮一 ${ }^{1}$, 市川亮介 ${ }^{1}$, 伊藤慎吾 ${ }^{1}$, 河野眞吾 ${ }^{1}$, 杉本起一 ${ }^{1}$, 神山博彦 ${ }^{1}$, 小見山博光 ${ }^{1}$, 小島豊 ${ }^{1}$, 五藤倫敏 ${ }^{1}$, 久末伸一 ${ }^{2}$, 堀江重郎 ${ }^{2}$, 寺尾泰久 ${ }^{3}$, 竹田省 ${ }^{3}$, 坂本一博

${ }^{1}$ 順天堂大学 医学部 下部消化管外科, ${ }^{2}$ 順天堂大学 医学部 泌尿器科， ${ }^{3}$ 順天 堂大学 医学部 産婦人科

【目的】癌の他臟器浸潤や不意な臟器損傷, 特殊状況下の手術など, 他科とのコラボ レーション手術 (コラボ) は疾患の根治性や安全性を高め, 患者に恩恵をもたらしてい る.コラボ手術を検討し，今後へのフィードバックを目的とした.【対象】 $2012 \sim 2015$ 年のコラボ症例 . コラボの定義は直接執刀だけでなく,コンサルト入入室した症例も含め, 消化器疾患の同時手術は除外した.【結果】コラボ手術数 131 例. 男 : 女 $=34: 97$ で女 性が多かった。主診療科は産婦人科 (産婦) 59 例, 当科 53 例, 泌尿器科 (泌尿) 7 例, 心臓血管外科 ( 心外) 5 例の順であった. 2 科コラボ 121 例, 3 科コラボ 9 例 , 4 科コラボ 1 例であった. 4 科コラボは回腸癌に対し回盲切 + 尿管切除 + 右属器切除 + 大腿動脈 バイパス術を施行した. 癌関連 90 例, 緊急 20 例, 臟器損傷 16 例であった. 当科術式 内訳は低位前方切除 28 例, 小腸切除 20 例, 回盲/右半切 20 例, S 状結腸切除 17 例の順であった.Hartmann, Miles を含むストマは 24 例 . 癌, 緊急, 臓器損傷ではストマ が多く, 緊急では有意に多かった $(\mathrm{p}=0.036)$. 産婦では子宮士卵巣摘出が 58 例, 泌尿 では尿管ステント 19 例, 膀胱切除 13 例が多かった.【ビデオ】コラボが有効であった 2 症例のビデオを供覧する.1. 巨大子宮筋腫と内膜症合併の直腸癌 , 2. 前立腺癌合併 直腸癌 (ロボット+腹腔鏡 $)$ 【まとめ】大腸癌や骨盤内手術では他科とのコラボを意識し た手術プランが重要で, 特に緊急時はストマが多く, 事前説明の重要性を再認識した。

\section{VSY2-3動脈合併切除再建症例に対する形成外科とのコラボレーション手術の現 状と治療成績}

久保博一 ${ }^{1}$, 森隆太郎 ${ }^{1}$, 松山隆生 ${ }^{1}$, 山田淳貴 ${ }^{1}$, 平谷清吾 ${ }^{1}$, 澤田雄 ${ }^{1}$,

大田洋平 ${ }^{1}$, 熊本宜文 ${ }^{1}$, 武田和永 ${ }^{1}$, 前川二郎 ${ }^{2}$, 遠藤格

${ }^{1}$ 横浜市立大学 医学部 消化器 - 腫瘍外科学, ${ }^{2}$ 横浜市立大学 医学部 形成外 科学

【目的】動脈合併切除症例に対する形成外科とのコラボレーション手術の現状と治療成 績を検討する。【対象と方法】術前に形成外科に併診しカンファレンスを実施、外科か ら合併切除部位、再建時の使用血管の選択肢を複数提示寸る. 当日は手術進渉状況 を連絡, 待機してもらう. 教室で経験した肝門部胆管癌切除 179 症例について動脈合 併切除の有無で治療成績を比較検討した。【結果】形成外科医不在での術式変更, 手術中止はなく, 術者交代に際して長時間待機はなかった.メリットは再建中スタッフの 休息が可能で, 手技の担保による安心感が挙げられる.デメリットは日程調整で手術予 定の変更, 延期があり得ること, 時間的な制約により手順を入れ替える場合があることで あった。肝門部胆管癌 179 例中 47 例 (26.2\%) で動脈再建を実施した。再建群 (R 群) と温存群 (P群)を比較すると R 群で手術時間が長かった $(\mathrm{R}: \mathrm{P}=914$ 分 :739 分, $\mathrm{p}=0.000)$. 一方, 出血量 (R:P = 2362ml:1958ml, $\mathrm{p}=0.299)$,Clavien-Dindo GradeIII 以上の合併 症 (R:P $=48 \%: 51 \%, p=0.926)$, 術後在院日数（R:P $=53.9$ 日: 39.2 日 , $\mathrm{p}=0.159 ）, \mathrm{R} 0$ 切除 率 (R:P=80.8\%:76.5\%) に差はなかった。再建動脈閉塞を 1 例 (2\%) 認めたが出血例はな かった。【結語】動脈再建症例に対する形成外科とのコラボレーション手術は若干の制 約があるが安全かつ円滑に施行可能で患者の安全に寄与すると考えられた. 形成外科 医の貢献度 , 拘束時間と労力からみて診療報酬上の加算が考慮されるべきと思われた。 


\section{VSY2-4＼cjkstart当院における皮弁再建を要する大腸癌治療}

進士誠一 ${ }^{1}$, 中尾淳一 ${ }^{2}$, 青木悠人 ${ }^{1}$, 菅隼人 ${ }^{1}$ ，山田岳史 ${ }^{1}$, 小泉岐博 ${ }^{1}$, 横山康行 ${ }^{1}$, 高橋吾郎 ${ }^{1}$, 岩井拓磨 ${ }^{1}$, 大草幹大 ${ }^{1}$, 藪野雄大 ${ }^{2}$, 梅澤裕己 ${ }^{2}$, 小川令 ${ }^{2}$, 太田惠一朗 ${ }^{1}$, 内田英二 ${ }^{1}$

${ }^{1}$ 日本医科大学 消化器外科, ${ }^{2}$ 日本医科大学 形成外科

【はじめに】悪性腫瘍が腹壁や会陰，腔などに浸潤し広範に切除する場合は，一期的 縫合閉鎖が困難であるため，再建方法を検討し準備する必要がある，当院では，形成 外科と合同で積極的に一期的切除再建を行っており，2014 年以降，4 例の有茥皮弁 再建を要する大腸癌症例を経験した。今回, 1 例のVideo と 3 例の術中写真を供覧する. 【症例 1 : Video】 66 歳, 女性. 右下腹部腫瘤を主訴に来院. 盲腸癌腹壁浸潤の診 断で，開腹回盲部切除 +腹壁合併切除を行った. 腹壁欠損部は有茎右前外側大腿皮 弁で再建し右大腿の欠損部には左大腿から分層植皮を行った。摘出標本の病理検査 の結果は tub2, pT4b(腹壁), N0, M0 Stage II. 術後経過は良好で術後 15 日目に退院. 【症例 2 : 術中写真】 79 歳, 女性. 腔浸潤を伴う直腸癌によるフルニエ症候群. S 状 結腸ス卜マ造設後，二期的に腹会陰式直腸切断術 +腔部分切除を行い，腔後壁欠損 部を皮弁で再建.【症例 3 : 術中写真】76 歳, 女性. 腔浸潤を伴う直腸癌. 腹腔鏡 下腹会陰式直腸切断術＋腔部分切除を行い，腔後壁を臀溝皮弁で再建.【症例 4 : 術中写真】68 歳, 男性. 左肛門挙筋浸潤を伴う直腸癌. 術前化学療法施行後に腹 腔鏡下腹会陰式直腸切断術を行い，会陰創欠損部を左大腿後筋皮弁で再建.【結語】 広範囲に浸潤する局所進行癌であっても根治切除が可能であれば良好な予後が期待 できるため，様々な再建方法を駆使し，チームで治瘉切除を目指すべきであると考える. 